\title{
Drug-induced Nephropathy and Molecular Patterns of Oxidative Stress
}

\author{
Valentina Lee ${ }^{1 \star}$, Ryszhan Bakirova ${ }^{1}$, Larissa Muravlyova ${ }^{2}$, Zhanara Turkhanova $^{1}$, Anar Rakhmetova $^{3}$ \\ ${ }^{1}$ Department of Internal Diseases, Karaganda Medical University, Karaganda-City, Kazakhstan; ${ }^{2}$ Department of Biochemistry, \\ Karaganda Medical University, Karaganda-City, Kazakhstan; ${ }^{3}$ Department of Defectology, Karaganda State University, \\ Karaganda-City, Kazakhstan
}

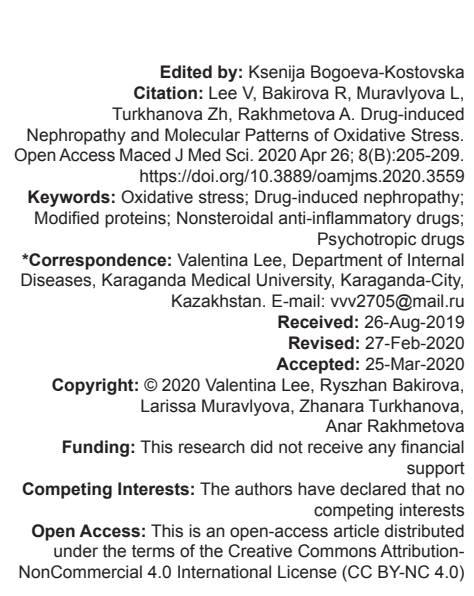

\section{Introduction}

In recent years, the number of medicinal lesions of the kidneys has become much more frequent in the practice of doctors of all specialties [1]. The reason is the continuous expansion of the medicines arsenal. Any drug may have potential nephrotoxicity. Drugs can cause damage with prolonged and uncontrolled use.

Approximately $20 \%$ of nephrotoxicity is induced by drugs [2], [3]. Medicinal lesions of the kidneys are one of the common causes of both acute and chronic nephropathy, endangering the patient's life. For example, in the structure of causes of end-stage renal failure, the role of analgesic injury has significantly increased in the past 20 years [4]. Moreover, a recent large database analysis raised concerns of potential acute kidney injury (AKI) risk associated with antipsychotics [5], [6] and cytotoxic effect of tricyclic antidepressants [7], [8], [9].

However, the molecular mechanisms of kidney damage in these cases are still poorly understood. It is believed that one of the possible damage mechanisms is oxidative stress. It has recently been shown that oxidative stress in the kidneys underlies acute nephrotoxicity caused by drugs. Proteins could be directly modified by reactive oxygen species (ROS) which leads to amino acid oxidation and crosslinking. The formation of oxidized modified proteins is accompanied by a loss of the protein functional activity, dysfunction of the conformation, the formation of aggregates, or fragmentation [10]. Carbonyl metabolic products include advanced oxidation protein products (AOPPs) and protein reactive carbonyl derivatives (PRCD) [11]. AOPPs have fairly pronounced biological properties similar to AGEs and can bind to the receptor for advanced glycation end products (RAGE) that lead to chronic kidney disease development [12]. Of particular interest is methylglyoxal one of the most reactive carbonyl compound, effecting on intracellular signaling systems [13]. One of the enzymes that play an important role in protecting cells against the toxic effects of oxidative stress is catalase (CAT). In human, it has been implicated in different physiological and pathological conditions [14]. 
Such an important aspect of oxidative stress as oxidative modification of proteins in the case of exogenous toxic nephropathies, including drug poisoning, is practically unstudied.

Thus, the problem of drug-induced nephropathies (DIP) is of increasing importance due to the multifactorial nature of damaging agents that tend to grow continuously, as well as the lack of knowledge of systemic and local (renal) response mechanisms. The main purpose of our study was to investigate the oxidative modifications of proteins in blood plasma and red blood cells of patients with DIP.

\section{Materials and Methods}

This prospective cross-sectional study was conducted on the basis of the biochemical laboratory of Karaganda Medical University, together with the Toxicological Department of the Regional Medical Center (from January 2017 to February 2018). Acute poisoning with remedies was diagnosed, considering the history of drug intake, physical examination, according to the clinical protocol recommended by the Expert Council of the Ministry of Health and Social Development of the Republic of Kazakhstan (August 25, 2016). Nephropathies were diagnosed by nephrologist according to medical history, an objective examination, urine parameters (proteinuria, macro/microhematuria, cylindruria, and decreased urine relative density) and reduced eGFR. eGFR was calculated according to serum creatinine concentration, using the Chronic Kidney Disease Epidemiology Collaboration formula (unit in $\mathrm{ml} / \mathrm{min} / 1.73 \mathrm{~m}^{2}$ ), serum neutrophil gelatinase-associated lipocalin (NGAL) level (as a sensitive biomarker for the early diagnosis of AKI) [15].

Exclusion criteria were the presence of acute infectious and inflammatory processes of other organs during the study period, as well as acute or chronic pyelonephritis of infectious etiology, acute or chronic glomerulonephritis, diabetes and/or diabetic nephropathy, obesity, and gestational nephropathy. In addition, persons younger than 18 years or older than 50 years were excluded from the study.

The study included 70 patients from 22 to 50 years old (43 females, 27 males; mean age 31.5; SD: 6.3). Thirty healthy donors (control group) served as a comparison group.

The first group consisted of 35 patients with psychotropic-induced nephropathy. All the patients in this group had poisoned with tricyclic antidepressants (in $90.1 \%$ cases, it was amitriptyline) to commit suicide.

About $45.8 \%$ of patients got drugs from relatives with different types of psychological disorders; in other cases, remedies were prescribed by neurologist or psychotherapist to cure insomnia (24.8\%) and depression (29.4\%).

The second group included 35 patients with nephropathy caused by nonsteroidal anti-inflammatory drugs (NSAIDs). The structure of NSAID suicidal poisoning was distributed as follows: Acetaminophen (43.5\%), diclofenac (22.8\%) ibuprofen (16.8\%), acetylsalicylic acid (9.3\%), and ketoprofen and ketorolac (7.6\%). All the patients had obtained NSAIDs easily from a retail pharmacy.

The control group was represented by individuals without clinical and laboratory signs of impaired renal function, absence of any drug intake at least 3 month.

\section{Blood sampling and biochemical analysis}

Blood sampling was carried out early in the morning on the $2^{\text {nd }}$ day of hospitalization since it is believed that this time is enough for a response of serum creatinine in the case of AKI [16]. Blood was stabilized by heparin. All blood tests were conducted within $2 \mathrm{~h}$ after the blood collection. Serum NGAL level was measured using a commercially available ELISA kit (Affymetrix eBioscience, Vienna, Austria); the unit of measure was $\mathrm{ng} / \mathrm{ml}$.

Biochemical measurements were carried out on a PD-303 UV A PEL spectrophotometer (Japan).

AOPP was measured spectrophotometrically as described by Witko-Sarsat et al. [15]. Briefly, $0.35 \mathrm{ml}$ of blood plasma and $1.75 \mathrm{ml}$ of sodium/potassium buffer solution were placed into a spectrophotometric cuvette and gently mixed, then $0.2 \mathrm{ml}$ of glacial acetic acid and $0.1 \mathrm{ml}$ of potassium iodide were added and measured at $340 \mathrm{~nm}$. A mixture of buffer solution, glacial acetic acid, and potassium iodide served as a control. The concentration of oxidative products of proteins containing bityrosine cross-links (AOPP) was expressed in $\mathrm{nmol} / \mathrm{l}$.

PRCD was assayed in blood plasma and erythrocytes by the method of Stadtman and Levine [17]. $0.1 \mathrm{ml}$ of blood plasma, $0.5 \mathrm{ml}$ of $20 \%$ trichloroacetic acid, and $0.5 \mathrm{ml}$ of dinitrophenylhydrazine were added to the centrifuge tube. The reaction mixture is incubated at room temperature for $1 \mathrm{~h}$ and centrifuged at $3000 \mathrm{rpm}$ for 5-7 min. Supernatant discarded. The obtained precipitate is resuspended in $0.5 \mathrm{ml}$ of ethyl acetate and centrifuged at $3000 \mathrm{rpm}$ for $3 \mathrm{~min}$. This procedure is repeated 2 times. The resulting precipitate is incubated at 37 for $18 \mathrm{~h}$. After incubation, $2 \mathrm{ml}$ of urea is added to the precipitate and measured on a spectrophotometer at $370 \mathrm{~nm}$. Distilled water serves as control.

Methylglyoxal was measured in blood plasma and erythrocytes according to the method of Racker et al. [16]. Twenty-five milliliters of samples were added to $350 \mathrm{ml} \mathrm{DNPH}(0.1 \% \mathrm{DNPH}$ in $2 \mathrm{n}$. $\mathrm{HCl})$. Then to each tube was added $2.125 \mathrm{ml}$ of distilled water. It was then incubated for $15 \mathrm{~min}$ at $37^{\circ} \mathrm{C}$. After incubation, $1.5 \mathrm{ml}$ of 
$10 \% \mathrm{NaOH}$ was added and the absorbance was read at $576 \mathrm{~nm}$ using a spectrophotometer.

CAT activity was determined in blood plasma and erythrocytes, according to Korolyuk et al. [18] and Aeby [19]. The first tube with $1.0 \mathrm{ml}$ hydrogen peroxide and $0.1 \mathrm{ml}$ distilled water, the second tube with $1.0 \mathrm{ml}$ distilled water and $0.1 \mathrm{ml}$ blood serum, and the third one with $1.0 \mathrm{ml}$ hydrogen peroxide and $0.1 \mathrm{ml}$ blood serum incubated at room temperature for $10 \mathrm{~min}$. Into all tubes was added $1.0 \mathrm{ml}$ ammonium molybdate. The intensity of the developed color is measured on a spectrophotometer at $\lambda=410 \mathrm{~nm}$ against a control sample and expressed in Units/ml.

\section{Statistical analysis}

The program Statistica for Windows, version 12 was used to analyze the received data. Oneway ANOVA for independent variables was used [20] to determine significant differences between the groups. The choice of this statistical method was due to the normal distribution of data (Shapiro-Wilk normality test, $p>0.05$ ) and homogeneity of variances (Levene's test, $p=0.591$ ) [21]. The differences were considered reliable at significance level $p<0.05$. The post-hoc Bonferroni test was used to identify pairs of samples, differing from each other in means. Parametric data are presented as mean \pm SD.

\section{Ethical issue}

The study was approved by the ethics committee of Karaganda Medical University and was conducted in accordance with the Helsinki Declaration. Informed consent was obtained from all the patients before their inclusion in the study. During the presence of patients in the toxicological department, all of them received standard therapy, corresponding to the poisoning severity and developed complications.

\section{Results}

Table 1 shows that carbonyl derivatives are significantly higher in red blood cells of the $1^{\text {st }}$ and

Table 1: PRCD, AOPP, and NGAL level in patients with DIP (MISD)

\begin{tabular}{|c|c|c|c|c|}
\hline \multirow[t]{2}{*}{ Groups } & \multicolumn{2}{|l|}{ PRCD } & \multirow{2}{*}{$\begin{array}{l}\text { AOPP } \\
\text { Blood plasma } \\
(\mathrm{nmol} / \mathrm{l})\end{array}$} & \multirow{2}{*}{$\begin{array}{l}\text { NGAL } \\
\text { Blood plasma } \\
\text { (pg/ml) }\end{array}$} \\
\hline & $\begin{array}{l}\text { Blood plasma } \\
\text { (nmol/l) }\end{array}$ & $\begin{array}{l}\text { Erythrocytes } \\
\text { (nmol/l) }\end{array}$ & & \\
\hline $\begin{array}{l}\text { (1 } 1^{\text {st }} \text { group) Patients } \\
\text { with psychotropic } \\
\text { drug-induced } \\
\text { nephropathy }\end{array}$ & $1.13 \pm 0.71$ & $14.93 \pm 2.66^{*}$ & $0.312 \pm 0.086^{*}$ & $332.2 \pm 112^{*}$ \\
\hline $\begin{array}{l}\text { nephropathy } \\
\left(2^{\text {nd }} \text { group) Patients }\right. \\
\text { with NSAID drug- } \\
\text { induced nephropathy }\end{array}$ & $0.78 \pm 1.62$ & $15.81 \pm 1.01^{*}$ & $0.301 \pm 0.09^{*}$ & $324.17 \pm 96^{*}$ \\
\hline Control subjects & $0.72 \pm 0.16$ & $10.76 \pm 1.26$ & $0.192 \pm 0.052$ & $80.49 \pm 85.13$ \\
\hline
\end{tabular}

$2^{\text {nd }}$ group patients compared to the control subjects $(p<0.001)$. AOPP statistically increased both in patients with various types of drug nephropathy when compared with the control group. However, there were no significant differences of the values, depending on the type of DIP.

As to the serum NGAL, it is significantly higher in 4 times compared to the control subjects $(p<0.01)$. No correlations of NGAL with other indicators were found.

The 2.5 times reduction of plasma CAT activities (Table 2 ) has been observed both in the group with psychotropic drug-induced nephropathy and in the group with NSAID drug-induced nephropathy $(p<0.01)$. As to the methylglyoxal level in erythrocytes, it was significantly higher in both patients' groups $(p<0.036$; $\mathrm{p}<0.04$ ) compared with control.

Table 2: CAT and methylglyoxal level in patients with DIP (M \pm SD)

\begin{tabular}{llllll}
\hline Groups & Catalase & & Methylglyoxal & \\
\cline { 2 - 3 } & $\begin{array}{l}\text { Blood } \\
\text { plasma }(\mathrm{U})\end{array}$ & $\begin{array}{l}\text { Erythrocytes } \\
(\mathrm{U})\end{array}$ & $\begin{array}{l}\text { Blood plasma } \\
(\mathrm{mg} / \mathrm{l})\end{array}$ & $\begin{array}{l}\text { Erythrocytes } \\
(\mathrm{mg} / \mathrm{l})\end{array}$ \\
\hline $\begin{array}{l}\left(1^{\text {st }} \text { group }\right) \text { Patients } \\
\text { with psychotropic drug- }\end{array}$ & $0.051 \pm 0.03^{*}$ & $0.25 \pm 0.14$ & $0.42 \pm 0.10$ & $0.92 \pm 0.12^{*}$ \\
$\begin{array}{l}\text { induced nephropathy } \\
\left(2^{\text {nd }} \text { group }\right) \text { Patients with }\end{array}$ & $0.049 \pm 0.04^{*}$ & $0.22 \pm 0.18$ & $0.43 \pm 0.11$ & $0.90 \pm 0.11^{*}$ \\
$\begin{array}{l}\text { NSAID drug-induced } \\
\text { nephropathy }\end{array}$ & & & & \\
Control subjects & $0.13 \pm 0.02$ & $0.30 \pm 0.16$ & $0.34 \pm 0.02$ & $0.55 \pm 0.08$ \\
\hline NSAID: Nonsteroidal anti-inflammatory drugs, DIP: Drug-induced nephropathies.
\end{tabular}

\section{Discussion}

Our data confirm the serum NGAL elevation even at the stage of nephropathy formation due to the development of acute oxidative stress. The high level of the serum NGAL was showed in patients with normal GFR. As NGAL expression increases in proximal tubule cells due to drug-induced nephrotoxicity or ischemia, it may be considered as a sensitive biomarker for early diagnosis of acute kidney damage.

Safety of psychotropic drugs is nowadays one of the most ambiguous research problems. Concerns regarding the possible detrimental effect of psychotropic medications on kidney function are supported by a recent meta-analysis [3], [4]. Recently, several independent researchers have reported that psychotropic remedies exhibit a cytotoxic effect in human cell cultures, increasing oxidative stress.

Moreno-Fernandez et al. and Hroudova and Fisar [5], [6], [7], [8] showed that tricyclic antidepressants specifically inhibited mitochondrial complex III activity due to low mitochondrial membrane potential. The decrease of cytochrome C, citrate synthase, and CAT activities leads to ROS overproduction. This, in turn, leads to a cascade process of protein oxidation and glycoxidation, resulting in excessive production of carbonyl derivatives, AOPP, methylglyoxal, and AGE products. 
The end glycation products are one of the factors of post-translational modification of proteins. They can also have an effect on the cell at the level of gene expression binding to specific cell surface receptors (RAGEs) that lead to phosphorylation of mitogenactivated protein kinases, activation of NF-kB, and secretion of pro-inflammatory cytokines [15]. Macrophage-mediated cell infiltration initiates AOPP production, exacerbating the course of nephropathy.

A pronounced increase of carbonyl derivatives, AOPP in patients with psychotropic drug-induced nephropathy and in patients with nephropathy caused by NSAIDs, may underlie specific mechanisms.

NSAIDs-induced nephrotoxicity is realized through several mechanisms of cell death. It has been established that drugs with the properties of acids (nitrosalicylic acid, acetylsalicylic acid, diclofenac, naproxen, ibuprofen, indomethacin, piroxicam, etc.) can inhibit mitochondrial oxidative phosphorylation ${ }^{2}$. In renal tubules, favorable conditions are created for the inhibitory effect of NSAIDs on oxidative phosphorylation. The uncoupling of oxidative phosphorylation and the loss of ATP leads to the disturbance of cellular ion homeostasis, namely, to the decrease of intracellular $\mathrm{K}+$ content and to the increase of $\mathrm{Na}+$ content that results in membrane depolarization and cell death. The disturbance of energy-dependent calcium homeostasis is also associated with the increased content of free $\mathrm{Ca}_{2}+$ in cytosol that plays a critical role in cell death [2].

Another nephrotoxicity mechanism of NSAIDs is associated with the formation of active metabolites. With the participation of cytochrome P-450 (mainly its isoform CYP2E1), the electrophilic intermediates are formed which, covalently bind to cell macromolecules, disrupting mitochondrial, and nuclear functions, thereby triggering ROS production, protein oxidation, and PRCD formation in erythrocytes. In patients with chronic kidney disease of the 1-2 stage, the carbonyl derivatives level in erythrocytes was in 3 times lower than in the control group. It can be explained by the conformation of the oxidized proteins and exposure of hydrophobic parts to the outside during the excessive PRCD formation, which creates conditions for the formation of protein-protein conglomerates and insoluble protein aggregates and causes the progression of nephropathy [12], [21].

In addition, when taking NSAIDs, an immunoallergic reaction can be developed which is characterized by macrophage interstitial infiltration the main producers of ROS and nitric oxide [2], whose targets are tyrosine residues in proteins, cytochromes, and myeloperoxidase, that is confirmed by the high level of AOPP in these patients. Each of the above mediators has a direct cytotoxic effect or is able to enhance the inflammatory response of tissues to other damaging factors.

\section{Conclusion}

Thus, the results of the present study permit us to draw the following conclusions. The patients with psychotropic and NSAIDs drug-induced nephropathy have increased level of oxidative stress products and increased NGAL level even in normal eGFR. The mechanisms that lead to the development of oxidative stress and the production of modified proteins are different in patients treated with different drugs. Establishing patterns of cell-molecular interaction permit the drug-induced nephropathy to be timely diagnosed and therapeutic programs to be optimized.

\section{Acknowledgments}

This study was supported by an interior grant from the Karaganda Medical University, devoted to the study of vasculogenesis and neutrophil reactivity in AKI.

\section{References}

1. Ghane Shahrbaf F, Assadi F. Drug-induced renal disorders. J Renal Inj Prev. 2015;4(3):57-60.

PMid:26468475

2. Kim SY, Moon A. Drug-induced nephrotoxicity and its biomarkers. Biomol Ther (Seoul). 2012;20(3):268-72.

PMid:24130922

3. Sales GT, Foresto RD. Drug-induced nephrotoxicity. Rev Assoc Med Bras (1922). 2020;66(1):82-90.

PMid:31939540

4. Ungprasert P, Cheungpasitporn W, Crowson CS, Matteson EL. Individual non-steroidal anti-inflammatory drugs and risk of acute kidney injury: A systematic review and meta-analysis of observational studies. Eur J Intern Med. 2015;26(4):285-91. https://doi.org/10.1016/j.ejim.2015.03.008 PMid:25862494

5. Correll CU, Detraux J, De Lepeleire J, De Hert M. Effects of antipsychotics, antidepressants and mood stabilizers on risk for physical diseases in people with schizophrenia, depression and bipolar disorder. World Psychiatry. 2015;14(2):119-36. https:// doi.org/10.1002/wps.20204

PMid:26043321

6. Jiang $\mathrm{Y}, \mathrm{McCombs}$ JS, Park SH. A retrospective cohort study of acute kidney injury risk associated with antipsychotics. CNS Drugs. 2017;31(4):319-26. https://doi.org/10.1007/ s40263-017-0421-4 PMid:28290080

7. Cordero MD, Sanchez-Alcazar JA, Bautista-Ferrufino MR, Carmona-López MI, Illanes M, Ríos MJ, et al. Acute oxidant damage promoted on cancer cells by amitriptyline in comparison with some common chemotherapeutic drugs. Anticancer Drugs. 2010;21(10):932-44. https://doi.org/10.1097/ cad.0b013e32833ed5f7 


\section{PMid:20847644}

8. Hroudova J, Fisar Z. In vitro inhibition of mitochondrial respiratory rate by antidepressants. Toxicol Lett. 2012;213(3):345-52. https://doi.org/10.1016/j.toxlet.2012.07.017

PMid:22842584

9. Taziki S, Sattari MR, Dastmalchi S, Eghbal MA. Cytoprotective effects of melatonin against amitriptyline-induced toxicity in isolated rat hepatocytes. Adv Pharm Bull. 2015;5(3):329-34. https://doi.org/10.15171/apb.2015.046 PMid:26504754

10. Muravlyova LE, Molotov-Luchanskiy VB, Kolesnikova YA. The modified proteins in erythrocytes and regulation of erythrocytes volume in patients with chronic kidney disease. Eur Rev Med Pharmacol Sci. 2015;19(22):4270-4. https://doi.org/10.1016/j. freeradbiomed.2014.10.775 PMid:26636513

11. Piwowar A. Advanced oxidation protein products. Part I. Mechanism of the formation, characteristics and property. Pol Merkur Lekarski. 2010;28(164):166-9.

PMid:20369749

12. Rabbani N, Thornalley PJ Advanced glycation end products in the pathogenesis of chronic kidney disease. Kidney Int. 2018;93(4):803-13. https://doi.org/10.1016/j.kint.2017.11.034 PMid:29477239

13. Husna AH, Ramadhani EA, Eva $D T$, Yulita $A F$, Suhartono $E$. The role formation of methylglyoxal, carbonyl compound, hydrogen peroxide and advance oxidation protein product induced cadmium in ovarian rat. Int J Chem Eng Appl. 2014;5(4):319-23. https://doi.org/10.7763/ijcea.2014.v5.402
14. Crawford A, Fasett RG, Coombes JS, Kunde DA, Ahuja KD, Robertson IK, et al. Glutathione peroxidase, superoxide dismutase and catalase genotypes and activities and the progression of chronic kidney disease. Nephrol Dial Transplant. 2011;26(9):2806-13. https://doi.org/10.1093/ndt/gfq828 PMid:21325350

15. Griffin BR, Faubel S, Edelstein CL. Biomarkers of drug-induced kidney toxicity. Ther Drug Monit. 2019;41(2):213-26. https://doi. org/10.1097/ftd.0000000000000589 PMid:30883514

16. Stadtman ER, Levine RL. Protein oxidation. Ann N Y Acad Sci. 2000;899:191-208.

PMid: 10863540

17. Witko-Sarsat V, Frielander M, Capeillere-Blandin C, NguyenKhoa T, Nguyen AT, Zingraff J, et al. Advanced oxidation protein products as a novel marker of oxidative stress in uremia. Kidney Int. 1996;49:1304-13. https://doi.org/10.1038/ki.1996.186 PMid:8731095

18. Racker E, Colowick SP, Kaplan NO. Methods in Enzymology Vol. 3. Cambridge: Academic Press; 1963. p. 283.

19. Korolyuk MA, Ivanova LI, Maĭorova IG, Tokarev VE. A method of determining catalase activity. Lab Delo. 1988;1:16-9. PMid:2451064

20. Aeby HE. Catalase in vitro. Methods Enzymol. 1984;105:121-6. PMid: 6727660

21. McDonald JH. Handbook of Biological Statistics. $3^{\text {rd }}$ ed. Baltimore, Maryland, USA: Sparky House Publishing; 2014. p. 146-8. 